\begin{tabular}{l|l}
\hline Votaice & $\begin{array}{l}\text { e-ISSN: 2655-9404 } \\
\text { DOI: } 10.20473 / \text { ntr.v1i1.9099 }\end{array}$ \\
\hline
\end{tabular}

Article history: Submitted 1 May 2018; Accepted 15 May 2018; Available online 1 June 2018.

\title{
Kedudukan Yayasan yang Belum Disesuaikan dengan Undang- Undang Yayasan Setelah Jangka Waktu Berakhir
}

\author{
Listya Aswaratika dan Dian Purnama Anugerah \\ listya.aswaratika-2016@fh.unair.ac.id \\ Universitas Airlangga
}

\begin{abstract}
Law Number 28 Year 2004 on The Amendment of Law Number 16 Year 2001 concerning Foundation ('Foundation Law') provides regulations on the adjustment of the Articles of Associations for foundations that were established before the establishment of the new Foundation Law. The adjustments for the Articles of Associations can be done within a certain time period granted by the law, it is a requirement for the Foundation to still hold the status of legal entity. Foundations that do not perform any adjustments to their Articles of Association, it will bring impact on the legitimacy of their legal actions and also the authority over the accountability of their legal actions. The purpose of this research is to analyze the legal status and the validity of the legal actions conducted by those Foundations who do not perform any adjustments to their articles of association in the given period. This legal research applies the research type of statute approach and conceptual approach. This research applies primary and secondary legal sources, and also applies interpretative and deductive analysis methods. The result of this research is the understanding on the validity of legal actions and the authority over the accountability of the legal actions, conducted by Foundations that do not perform any adjustments to their Articles of Association.
\end{abstract}

Keywords: Foundation; Articles of Association; Adaptation.

\begin{abstract}
Abstrak
Undang-Undang Nomor 28 tahun 2004 tentang Perubahan Atas Undang-Undang Nomor 16 tahun 2001 tentang Yayasan mengatur mengenai penyesuaian anggaran dasar bagi yayasan yang telah lahir sebelum berlakunya Undang-Undang Yayasan. Penyesuaian dilakukan dalam jangka waktu yang telah diberikan oleh Undang-Undang Yayasan dengan tujuan agar yayasan tersebut tetap mendapatkan status badan hukum. Namun terhadap yayasan yang tidak melakukan penyesuaian anggaran dasar tersebut akan berdampak pada keabsahan perbuatan hukum yang dilakukan oleh yayasan dan kewenangan terhadap pertanggungjawaban atas perbuatan hukum yang dilakukan. Tujuan penelitian ini untuk menganalisa status hukum yayasan yang hingga jangka waktu berakhir belum melakukan penyesuaian Anggaran Dasar dengan Undang-Undang Yayasan, serta mengenai keabsahan tindakan hukum yang dilakukan yayasan apabila yayasan tersebut belum menyesuaikan dengan Undang-Undang Yayasan. Penelitian ini menggunakan tipe penelitian hukum dengan menggunakan pendekatan perundang-undangan dan pendekatan konseptual. Sumber bahan hukum dalam penelitian ini yaitu primer dan sekunder, serta menggunakan metode interpretasi dan metode deduktif analisis untuk menganalisa bahan hukum tersebut. Kemudian hasil dari penelitian ini ialah mengetahui keabsahan perbuatan hukum yang dilakukan yayasan jika yayasan hingga jangka waktu berakhir belum melakukan penyesuaian anggaran dasar yayasannya dengan Undang-Undang Yayasan dan kewenangan terhadap pertanggungjawaban atas perbuatan hukum yang dilakukan.
\end{abstract}

Kata Kunci: Yayasan; Anggaran Dasar; Penyesuaian. 


\section{Pendahuluan}

Sebelum lahirnya Undang-Undang Nomor 16 tahun 2001 tentang Yayasan, aturan mengenai Yayasan di Indonesia berdasarkan pada kebiasaan-kebiasaan yang berkembang di masyarakat serta berdasarkan yurisprudensi-yurisprudensi Mahkamah Agung. Hal ini kemudian berdampak pada beragamnya bentuk dan tata cara pendirian yayasan. Pada umumnya, masyarakat menggunakan akta notaris dalam hal mendirikan yayasan, namun hal tersebut tidak tertuang dalam suatu peraturan tertulis sehingga tidak menjadi kewajiban bagi pendiri untuk menggunakan akta notaris dalam hal pendirian yayasan. Tidak adanya aturan yang secara khusus mengatur mengenai yayasan membuat banyak orang mendirikan yayasan sebagai dalih untuk berlindung dibalik status badan hukum yayasan. Yayasan yang menjalankan fungsi sosial dan memiliki karakteristik yang bersifat non komersial sering kali disalahgunakan menjadi suatu organisasi yang mengejar keuntungan sehingga menyimpang dari prinsip yayasan.

Hal tersebut menjadi dasar lahirnya Undang-Undang Nomor 16 tahun 2001 tentang yayasan yang kemudian dilakukan perubahan menjadi Undang-Undang Nomor 28 tahun 2004 tentang perubahan atas Undang-Undang Nomor 16 tahun 2001 tentang yayasan (Selanjutnya disebut Undang-Undang Yayasan). Dalam Undang-Undang Yayasan mengatur bahwa yayasan yang lahir sebelum undangundang yayasan tetap memperoleh status badan hukum dengan cara yayasan tersebut menyesuaikan anggaran dasar yayasannya dengan undang-undang yayasan. Namun dalam faktanya masih banyak yayasan yang tidak melakukan penyesuaian hingga jangka waktu yang diberikan undang-undang berakhir. Padahal undang-undang telah memberikan sanksi terhadap yayasan yang tidak melakukan penyesuaian, tetapi yayasan tersebut masih tetap melakukan kegiatan yayasan tanpa menghiraukan sanksi yang telah diberikan oleh undang-undang.

Berdasarkan latar belakang tersebut kemudian muncul dua rumusan masalah, yang pertama mengenai status hukum yayasan yang hingga jangka waktu berakhir belum melakukan penyesuaian Anggaran Dasar dengan Undang-Undang Yayasan. Kemudian rumusan masalah yang kedua yaitu tentang keabsahan tindakan hukum 
yang dilakukan Organ Yayasan apabila yayasan tersebut belum menyesuaikan dengan Undang-Undang Yayasan.

Untuk menjawab dua rumusan masalah tersebut, maka digunakan beberapa pendekatan yaitu pendekatan perundang-undangan (statute approach) dan juga menggunakan pendekatan konseptual (conceptual approach). Pendekatan perundang-undangan (statute approach) adalah suatu penelitian hukum yang menempatkan pendekatan peraturan perundang-undangan sebagai salah satu pendekatan. ${ }^{1}$ Kemudian pendekatan konseptual (conceptual approach) adalah penelitian hukum yang beranjak dari pandangan-pandangan dan doktrin-doktrin yang berkembang dalam ilmu hukum. ${ }^{2}$

\section{Pengertian dan Tata Cara Pendirian Yayasan}

Yayasan adalah salah satu bentuk badan hukum yang tidak memiliki anggota, dimana kekayaan yayasan tersebut berasal dari kekayaan para pendiri yang kemudian dipisahkan dari para pendiri dan diperuntukkan untuk mencapai tujuan tertentu di bidang sosial, keagamaan dan kemanusiaan. Status badan hukum yang diperoleh yayasan, membuat yayasan menjadi subyek hukum. Artinya yayasan sebagai subyek hukum bahwa yayasan dapat melakukan tindakan dalam lalu lintas hukum secara mandiri yang terlepas hak dan kewajibannya dengan organ-organ yayasan.

Sebelum adanya Undang-Undang Yayasan, pada umumnya pendirian yayasan dilakukan dengan menggunakan akta notaris. Namun tidak ada keharusan bagi Pengurus yayasan untuk mendaftarkan akta pendirian yayasan tersebut ke Pengadilan dan kemudian mengumumkannya di Tambahan Berita Negara. Namun setelah berlakunya Undang-Undang Yayasan mewajibkan yayasan untuk mendaftarkan akta pendirian yayasannya tersebut ke Pengadilan dan kemudian mengumumkannya di Tambahan Berita Negara. Dengan adanya Undang-Undang Yayasan, berarti bahwa tentang tata cara pendirian Yayasan tidak lagi didasarkan pada kebiasaan dan yurisprudensi seperti yang dilakukan pada saat belum ada

\footnotetext{
${ }^{1}$ Peter Mahmud Marzuki, Penelitian Hukum (Kencana Prenadamedia Group 2014).[136].

${ }^{2}$ ibid. [177].
} 
Undang-Undang Yayasan. Pendirian Yayasan saat ini haruslah sesuai dengan yang telah diatur dalam Undang-Undang Yayasan. Undang-Undang Yayasan mengatur mengenai tiga proses yang perlu diperhatikan dalam pendirian yayasan yaitu: ${ }^{3}$

a. Proses pendirian yayasan

Untuk melakukan suatu pendirian yayasan ada beberapa persyaratan yang harus dipenuhi, bahwa yayasan tersebut harus didirikan minimal oleh satu orang yang kemudian akan disebut sebagai pendiri yayasan. Kemudian pendiri/para pendiri tersebut harus memasukkan sejumlah harta kekayaan pribadinya untuk dipisahkan dan menjadi kekayaan awal yayasan. Pembuatan akta pendirian yayasan harus dilakukan oleh notaris dengan syarat akta tersebut menggunakan bahasa indonesia, didahului dengan kata "Yayasan" didepan namanya, nama yayasan yang akan digunakan tidak boleh menggunakan nama yayasan yang secara sah telah ada sebelumnya dan tidak boleh bertentangan dengan ketertiban umum dan/atau kesusilaan. Kemudian akta pendirian tersebut harus diajukan permohonan kepada menteri untuk mendapatkan pengesahan. Setelah proses pengesahan selesai, akta pendirian tersebut diumumkan dalam Tambahan Berita Negara Republik Indonesia. b. Proses pengesahan akta yayasan

Setelah lahirnya Undang-Undang Yayasan, pengesahan akta pendirian yayasan wajib dilakukan untuk memperoleh status badan hukum. Untuk mengajukan permohonan pengesahan yayasan, dalam jangka waktu 10 (sepuluh) hari terhitung sejak tanggal akta pendirian yayasan ditandatangani, pendiri mengajukan permohonan kepada Menteri yang terkait melalui notaris yang membuat akta pendirian yayasan tersebut. Permohonan pengesahan badan hukum yayasan secara elektronik maupun non elektronik telah diatur didalam Peraturan Menteri Hukum dan Hak Asasi Manusia Republik Indonesia Nomor 5 tahun 2014 tentang Pengesahan Badan Hukum Yayasan.

c. Proses pengumuman yayasan sebagai badan hukum.

Didalam Undang-Undang Yayasan, pengumuman akta pendirian yayasan

\footnotetext{
${ }^{3}$ Suyud Margiono, Badan Hukum Yayasan Dinamika Praktek, Efektifitas \& Regulasi Di Indonesia (Pustaka Reka Cipta 2015).[59].
} 
yang telah disahkan dilakukan oleh Menteri dalam jangka waktu 14 (empat belas) hari terhitung sejak akta pendirian yayasan tersebut disahkan. Ketentuan lebih lanjut mengenai tata cara pengumuman yayasan dalam Tambahan Berita Negara Republik Indonesia diatur dalam Peraturan Menteri Hukum dan Hak Asasi Manusia Republik Indonesia Nomor M.HH-02.AH.02.01 tahun 2010 tentang Tata Cara Pengumuman Yayasan dalam Tambahan Berita Negara Republik Indonesia.

\section{Organ Yayasan}

Badan hukum, dalam bahasa Belanda "Rechtpersoon", ialah suatu badan yang dapat mempunyai harta kekayaan, hak serta kewajiban seperti orang-orang pribadi. ${ }^{4}$ Badan hukum dapat melakukan perbuatan-perbuatan hukum seperti orang-orang pribadi, tetapi badan hukum tidak dapat melakukannya sendiri karena pada dasarnya badan hukum adalah "orang ciptaan hukum" (artificial persoon) yang hanya dapat melakukan perbuatan hukum dengan perantara manusia sebagai wakilnya. ${ }^{5}$ Sehingga badan hukum membutuhkan manusia sebagai bentuk representative untuk dapat melakukan perbuatan hukum untuk dan atas nama badan hukum tersebut. Orang-orang yang bertindak untuk dan atas nama pertanggungjawaban badan hukum Yayasan kemudian disebut sebagai organ Yayasan. ${ }^{6}$

Organ yayasan terdiri dari Pembina, Pengurus, dan Pengawas. Pembina adalah organ tertinggi didalam suatu yayasan karena ia memiliki kewenangan yang tidak diserahkan ke organ lainnya yaitu Pengurus maupun Pengawas. Pengurus adalah salah satu dari organ yayasan yang mempunyai wewenang untuk melaksanakan kegiatan kepengurusan yayasan. Kemudian yang memiliki wewenang untuk melakukan tugas kepengawasan terhadap tindakan kepengurusan yayasan yang dilakukan oleh Pengurus adalah Pengawas. Dimana masing-masing organ yayasan tersebut memiliki tugas dan wewenang yang berbeda-beda antar satu organ dengan organ lainnya. Pemisahan secara tegas antara fungsi, wewenang dan tugas

\footnotetext{
${ }^{4}$ Rochmat Soemitro, Hukum Perseroan Terbatas, Yayasan Dan Wakaf (Eresco 1993).[10].

${ }^{5}$ Anwar Borahima, Kedudukan Yayasan Di Indonesia Eksistensi, Tujuan, Dan Tanggung Jawab Yayasan (Kencana 2010).[199].

${ }^{6}$ ibid.[200].
} 
masing-masing dari organ yayasan ini serta hubungan antar organ yayasan tersebut dimaksudkan untuk menghindari kemungkinan akan adanya pertengkaran dalam organ yayasan itu sendiri yang tidak hanya dapat merugikan kepentingan yayasan melainkan dapat pula merugikan pihak ketiga.

\section{Aset Yayasan}

Syarat utama dalam pendirian yayasan yaitu yayasan harus mempunyai kekayaan yang dipisahkan. Setelah kekayaan tersebut dipisahkan dari kekayaan si pendiri yayasan, maka kekayaan tersebut secara hukum telah beralih menjadi milik yayasan yang pengelolaannya dilakukan sepenuhnya oleh organ yayasan untuk menjalankan kegiatan yayasan. Kekayaan dari para pendiri yang dipisahkan tersebut tidak berarti memberikan hak bagi para pendiri yayasan terhadap kepemilikan maupun kepengurusan yayasan, melainkan kekayaan tersebut murni menjadi kekayaan awal yayasan. Kekayaan yayasan yang dipisahkan bisa berupa uang atau barang, dengan syarat jika barang-barang tersebut harus sama nilainya dengan jumlah minimum yang telah ditetapkan. Sumber kekayaan yayasan selain yang didapatkan dari pemisahan kekayaan para pendiri, juga dapat berasal dari sumber-sumber lain seperti dari sumbangan-sumbangan atau bantuan yang tidak mengikat dari pihak diluar yayasan; wakaf; hibah maupun hibah wasiat kepada yayasan maupun sumber kekayaan yang berasal dari perolehan lain selama perolehan tersebut tidak bertentangan dengan anggaran dasar yayasan tersebut dan tidak bertentanagn dengan peraturan perundang-undangan. ${ }^{7}$ Karena yayasan bertujuan untuk kepentingan sosial, sehingga perolehan yang berasal dari sumbersumber tersebut dapat dilakukan meskipun tanpa adanya hubungan timbal balik yang menimbulkan hak dan kewajiban diantara para pihak.

Terkait dengan aset yayasan yang telah didirikan sebelum berlakunya Undang-Undang Yayasan, maka dalam hal penyesuaian anggaran dasar, mantan pengurus yayasan yang terakhir kali dalam perubahan anggaran dasar Yayasan

\footnotetext{
${ }^{7}$ Pasal 26 ayat 2 Undang-Undang Nomor 28 tahun 2004 tentang Perubahan Atas Undang-Undang Nomor 16 tahun 2001 tentang Yayasan.
} 
yang berhak mengajukan permohonan penyesuaian anggaran dasar. Dengan syarat harus dengan melampirkan premis akta yang isinya berupa pengalihan aset yayasan yang dilakukan oleh likuidator dengan menggunakan akta Notaris. Hal ini dilakukan karena dalam pendirian yayasan telah diatur bahwa adanya pemisahan sebagian harta kekayaan Pendiri sebagai kekayaan awal yayasan, sehingga bukan berarti bahwa aset yayasan lama yang hendak dilakukan penyesuaian anggaran dasar dengan Undang-Undang Yayasan serta merta menjadi kekayaan awal yayasan yang baru atau yayasan yang telah disesuaikan anggaran dasarnya. Namun terhadap aset tersebut harus dilakukan pengalihan aset kekayaan dari yayasan lama atau yang belum dilakukan penyesuaian anggaran dasar ke yayasan baru atau yayasan yang telah disesuaikan anggaran dasarnya dengan Undang-Undang Yayasan.

\section{Kewajiban Menyesuaikan Anggaran Dasar Yayasan Dengan Undang-Undang Yayasan}

Ketentuan yang ada didalam Undang-Undang Yayasan mewajibkan yayasan yang lahir sebelum Undang-Undang Yayasan untuk melakukan penyesuaian anggaran dasar yayasannya dengan undang-undang yayasan dalam jangka waktu yang telah ditentukan. Dengan demikian, yayasan yang lahir baik sebelum maupun setelah berlakunya Undang-Undang Yayasan telah diakui sebagai badan hukum setelah melakukan penyesuaian anggaran dasar yayasannya. Dengan konsekuensi bahwa yayasan yang lahir sebelum berlakunya Undang-Undang Yayasan harus mematuhi ketentuan peralihan yang ada didalam Undang-Undang Yayasan. Sehingga dapat ditegaskan bahwa yayasan yang telah ada tetap diakui sebagai badan hukum apabila telah memenuhi syarat-syarat sebagaimana disebutkan dalam pasal 71 ayat 1 dan ayat 3 Undang-Undang Nomor 28 tahun 2004 tentang Perubahan Atas Undang-Undang Nomor 16 tahun 2001 tentang Yayasan.

Yayasan yang telah didirikan namun belum didaftarkan di Pengadilan Negeri dan diumumkan dalam Tambahan Berita Negara Republik Indonesia ataupun belum didaftarkan di Pengadilan Negeri dan mempunyai izin melakukan kegiatan dari 
instansi terkait tidak serta merta yayasan tersebut langsung menjadi badan hukum, melainkan ia dapat memperoleh status badan hukum dengan cara mengajukan permohonan kepada Menteri dalam jangka waktu paling lambat 1 (satu) tahun terhitung sejak tanggal Undang-Undang Yayasan berlaku.

Lahirnya Peraturan Pemerintah Republik Indonesia Nomor 2 tahun 2013 tentang Perubahan Atas Peraturan Pemerintah Nomor 63 tahun 2008 tentang Pelaksana Undang-Undang tentang Yayasan mengatur lebih lanjut bagi yayasan yang belum melakukan penyesuaian anggaran dasar yayasan dengan ketentuan Undang-Undang, tetap dapat melakukan penyesuaian anggaran dasar meskipun jangka waktu bagi yayasan tersebut untuk melakukan penyesuaian sebagaimana diatur dalam Undang-Undang Yayasan telah berakhir. Atas dasar itulah Direktorat Jenderal Administrasi Hukum Umum Kementerian Hukum Dan Hak Asasi Manusia Republik Indonesia tidak menolak apabila ada yayasan yang mendaftarkan untuk melakukan penyesuaian anggaran dasar dan untuk mendapatkan pengesahan badan hukum yayasannya meskipun jangka waktu yang diberikan oleh Undang-Undang Yayasan telah berakhir. ${ }^{8}$

Peraturan Pemerintah Republik Indonesia Nomor 2 tahun 2013 tentang Perubahan Atas Peraturan Pemerintah Nomor 63 tahun 2008 tentang Pelaksana Undang-Undang tentang Yayasan membedakan penyesuaian anggaran dasar terhadap yayasan yang belum diakui sebagai badan hukum setelah berlakunya Undang-Undang Yayasan dengan yayasan yang diakui sebagai badan hukum setelah berlakunya Undang-Undang Yayasan.

Tabel 1. Perbedaan Cara Penyesuaian Yayasan Yang Belum Diakui Sebagai Badan Hukum Dengan Yayasan Yang Telah Diakui Sebagai Badan Hukum

Yayasan yang belum diakui sebagai Badan Hukum
Yayasan yang telah diakui sebagai Badan Hukum

\footnotetext{
${ }^{8}$ Ana Ferliana, 'Badan Hukum Yayasan dan Perkumpulan Pasca Disahkannya UU ORMAS' Pelatihan Penggunaan Layanan AHU Online,, disampaikan di Ruang Pertemuan Hotel Harris Surabaya, (KEMENKUMHAM 2015).[4].
} 
Berlaku Pasal 15 A PP Nomor 2 Tahun 2013:

Berlaku Pasal 37 A PP Nomor 2 Tahun 2013:

a. Salinan akta pendirian Yayasan yang dalam premise aktanya menyebutkan asalusul pendirian Yayasan termasuk kekayaan Yayasan yang bersangkutan;

b. Laporan kegiatan Yayasan paling sedikit selama 5 (lima) tahun terakhir secara berturut-turut yang ditandatangani oleh Pengurus Yayasan dan diketahui oleh instansi

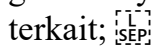

c. Surat pernyataan Pengurus Yayasan bahwa Yayasan tidak pernah dibubarkan secara sukarela atau berdasarkan putusan pengadilan;

d. Fotokopi Nomor Pokok Wajib Pajak d. Yayasan yang telah dilegalisir oleh notaris; isłp;

e. Surat pernyataan tempat kedudukan disertai alamat lengkap Yayasan yang ditandatangani oleh Pengurus Yayasan dan diketahui

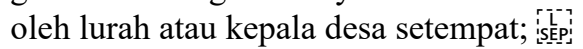

f. Pernyataan tertulis dari Pengurus Yayasan yang memuat keterangan nilai kekayaan pada saat penyesuaian Anggaran Dasar; isciep]

g. Surat pernyataan Pengurus mengenai keabsahan kekayaan Yayasan; dan

h. Bukti penyetoran biaya pengesahan dan pengumuman Yayasan.

i. Permohonan pengesahan akta pendirian Yayasan dilakukan dengan cara elektronik yaitu secara online (melalui Sistem Administrasi Badan Hukum /SABH) yang diselenggarakan oleh Direktorat Jenderal Administrasi Hukum Umum.

a. Salinan akta perubahan seluruh Anggaran Dasar yang dilakukan dalam rangka penyesuaian dengan ketentuan Undang-Undang; is

b. Tambahan Berita Negara Republik Indonesia yang memuat akta pendirian Yayasan atau bukti pendaftaran akta pendirian di pengadilan negeri dan izin melakukan kegiatan dari instansi terkait; iș̣p?

c. Laporan kegiatan Yayasan selama 5 (lima) tahun berturut-turut sebelum penyesuaian Anggaran Dasar yang ditandatangani oleh Pengurus dan diketahui oleh instansi terkait; :

d. Surat pernyataan Pengurus Yayasan bahwa Yayasan tidak pernah dibubarkan secara sukarela atau berdasarkan putusan pengadilan;

e. Fotokopi Nomor Pokok Wajib Pajak Yayasan yang telah dilegalisir oleh notaris;

f. Surat pernyataan tempat kedudukan disertai alamat lengkap Yayasan yang ditandatangani oleh Pengurus Yayasan dan diketahui oleh lurah atau kepala desa setempat;

g. Neraca Yayasan yang ditandatangani oleh semua anggota organ Yayasan atau laporan akuntan publik mengenai kekayaan Yayasan pada saat penyesuaian;

h. Pengumuman surat kabar mengenai ikhtisar laporan tahunan bagi Yayasan yang sebagian kekayaannya berasal dari bantuan negara, bantuan luar negeri, dan/atau sumbangan masyarakat sebagaimana dimaksud dalam Pasal 72 Undang-Undang; dan

i. Bukti penyetoran biaya pemberitahuan perubahan Anggaran Dasar Yayasan dan pengumumannya.

j. Pemberitahuan perubahan Anggaran Dasar dilakukan dengan cara mengajukan dokumen fisik dan proses pengajuan badan hukumnya dilakukan manual dengan mengirim pengajuannya ke Direktur Perdata Departemen Hukum dan Hak Asasi Manusia.

Sumber: Peraturan Pemerintah Nomor 2 tahun 2013 tentang Perubahan Atas Peraturan Pemerintah Republik Indonesia Nomor 63 tahun 2008 tentang Pelaksanaan Undang-Undang tentang Yayasan.

\section{Akibat Hukum Yayasan yang Tidak Menyesuaikan Anggaran Dasar Dengan Undang-Undang Yayasan}

Penyesuaian anggaran dasar dan pemberitahuan kepada Menteri terhadap Yayasan yang telah ada sebelum berlakunya Undang-Undang Yayasan merupakan 
suatu kewajiban yang telah diatur dalam Undang-Undang Yayasan. Karena merupakan kewajiban sudah tentu hal ini tidak boleh disimpangi. Karena konsekuensi dari adanya suatu kewajiban sudah tentu akan adanya sanksi apabila kewajiban tersebut tidak dilaksanakan oleh pihak yang bersangkutan. UndangUndang Yayasan telah mengatur mengenai sanksi administratif terhadap yayasan yang telah ada sebelum berlakunya Undang-Undang Yayasan yang tidak melakukan penyesuaian dengan Undang-Undang Yayasan, yaitu bahwa Yayasan tersebut tidak dapat lagi menggunakan kata "Yayasan" didepan namanya dan yayasan tersebut dapat pula dibubarkan berdasarkan pada putusan Pengadilan atas permohonan dari Kejaksaan atau atas permohonan dari pihak-pihak yang berkepentingan. ${ }^{9}$

Tidak menggunakan kata "Yayasan" didepan namanya hal ini berarti bahwa yayasan tersebut telah lepas dari status badan hukum yang melekat ketika ia masih menggunakan kata yayasan didepan namanya. Hal ini kemudian berakibat pada keabsahan status badan hukum yayasan tersebut. Yang mana jika suatu yayasan yang tidak lagi menggunakan kata yayasan didepan namanya berarti yayasan tersebut tidak diakui lagi sebagai badan hukum. Sehingga berakibat terhadap seluruh perbuatan yang dilakukan oleh yayasan tersebut tidak lagi menjadi pertanggungjawaban badan hukum yayasan itu meskipun perbuatan tersebut dilakukan untuk dan atas nama yayasan. Karena dengan menggunakan kata "Yayasan", ini berarti Yayasan tersebut telah menjadi badan hukum dengan segala tanggung jawab organnya berdasarkan pertanggungjawaban layaknya sebagai suatu badan hukum. ${ }^{10}$ Perbuatan tersebut melainkan menjadi tanggung jawab organ-organ yang ada didalamnya secara pribadi bahkan sampai bertanggung renteng sampai dengan harta kekayaan pribadi atas perbuatan yang dilakukannya sebagai organ.

Yayasan dapat pula dibubarkan berdasarkan putusan Pengadilan atas permohonan kejaksaan dan pihak yang berkepentingan. Dalam aturan tersebut kata "dapat dibubarkan" memiliki arti bahwa, aturan tersebut bukanlah suatu norma

9 Pasal 71 ayat (4) Undang-Undang Nomor 28 tahun 2004 tentang Perubahan Atas Undang-Undang Nomor 16 tahun 2001 tentang Yayasan.

${ }^{10}$ Suyud Margiono.Op.Cit.[97]. 
perintah bagi pelaksana undang-undang untuk mentaatinya. Kata "dapat" dalam aturan tersebut mengandung dua makna bahwa aturan tersebut bisa dilakukan dan aturan tersebut bisa juga untuk tidak dilakukan. Karena berupa pilihan dan tidak secara tegas mewajibkan maka aturan ini penerapannya lemah dan sebenarnya bisa menimbulkan suatu ketidakpastian hukum.

Jika melihat pada kedua aturan diatas, jelas terlihat bahwa terdapat dua aturan yang saling kontradiksi. Untuk dapat menyelesaikan permasalahan tersebut dapat digunakan asas Principium tertii exclusi atau azas penyisihan kemungkinan ketiga yang menyatakan bahwa kemungkinan yang ketiga itu tidak ada. Yang berarti bahwa apabila ada dua keputusan yang kontradiktori pastilah salah satu diantaranya salah. Hal ini karena keputusan yang satu merobohkan keputusan yang lain, sebab tidak mungkin kedua-duanya sama-sama benar atau sama-sama salah. ${ }^{11}$

Dalam menerapkan asas tersebut, maka jika mengikuti aturan yang pertama bahwa yayasan tersebut tidak dapat lagi menggunakan kata yayasan didepan namanya hal ini berarti bahwa yayasan tersebut telah lepas dari status badan hukum yang melekat ketika ia masih menggunakan kata yayasan didepan namanya. Hal ini kemudian berakibat pada keabsahan status organisasi. Yang mana jika suatu yayasan yang tidak lagi menggunakan kata yayasan didepan namanya berarti yayasan tersebut tidak diakui lagi sebagai badan hukum yang dapat melakukan perbuatan hukum atas nama badan hukum itu sendiri. Sehingga berakibat terhadap seluruh perbuatan yang dilakukan oleh organisasi tersebut tidak lagi menjadi pertanggungjawaban badan hukum yayasan itu meskipun perbuatan tersebut dilakukan untuk dan atas nama yayasan. Perbuatan tersebut melainkan menjadi tanggung jawab organ-organ yang ada didalamnya secara pribadi bahkan sampai bertanggung renteng sampai dengan harta kekayaan pribadi atas perbuatan yang dilakukannya sebagai organ.

Aturan kedua mengatur mengenai pembubaran yayasan atas permohonan di Pengadilan. dalam aturan tersebut mengatur bahwa yayasan dapat dibubarkan berdasarkan putusan Pengadilan atas permohonan Kejaksaan atau pihak yang

\footnotetext{
${ }^{11}$ Alex Lanur OFM, Logika Selayang Pandang (Kanisius 1983).[58].
} 
berkepentingan. Terdapatnya kata "dapat dibubarkan" memiliki arti bahwa yang pertama bahwa aturan tersebut bukanlah suatu keharusan atau kewajiban bagi pelaksana undang-undang untuk mentaatinya. Kata dapat dalam aturan tersebut mengandung dua makna bahwa aturan tersebut bisa dilakukan dan aturan tersebut bisa juga untuk tidak dilakukan. Karena berupa pilihan dan tidak secara tegas mengatur maka aturan ini lebih lemah penerapannya jika dibandingkan dengan aturan pertama. Sehingga seharusnya yang menjadi acuan dalam penegakkan aturan mengenai penyesuaian yayasan adalah aturan yang pertama yang menyatakan bahwa yayasan tersebut tidak dapat lagi menggunakan kata "yayasan" didepannya.

Kemudian diperkuat bahwa tidak mungkin apabila yayasan tersebut yang sudah tidak dapat lagi menggunakan kata yayasan didepan namanya dapat dijadikan sebagai Termohon dalam permohonan pembubaran yayasan oleh kejaksaan atau pihak yang berkepentingan. Hal ini mungkin saja terjadi apabila yayasan tersebut masih berstatus badan hukum, namun dalam hal ini dimana yayasan tersebut tidak dapat lagi menggunakan kata yayasan didepan namanya sudah berarti bahwa yayasan tersebut bukanlah diakui sebagai badan hukum lagi. Sehingga yayasan tersebut tidak dapat dijadikan sebagai Termohon dalam proses pembubaran yayasan atas dasar permohonan di pengadilan. Maka aturan yang kedua dalam pasal 71 ayat (4) Undang-Undang Yayasan seharusnya tidak dapat dijadikan acuan karena mengandung cacat hukum.

Aturan kedua lebih tepat jika digunakan apabila yayasan yang tidak mengindahkan aturan yang pertama bahwa yayasan tersebut meskipun sudah diatur untuk tidak lagi menggunakan kata yayasan didepannya namun yayasan tersebut tetap menggunakan kata yayasan didepan namanya dan tetap melakukan perbuatan hukum sebagaimana halnya yayasan tersebut masih memiliki status badan hukum, barulah kemudian dapat diajukan permohonan pembubaran yayasan oleh kejaksaan, maupun pihak yang berkepentingan.

Hal-hal seperti yang telah dijelaskan diataslah yang menjadi permasalahanpermasalahan tentang yayasan di Indonesia saat ini. Masih banyak yayasan yang telah ada sebelum berlakunya Undang-Undang Yayasan namun belum menyesuaikan 
Anggaran Dasarnya dengan ketentuan didalam Undang-Undang Yayasan. Bahkan hingga jangka waktu yang diberikan Undang-Undang Yayasan untuk menyesuaikan berakhir pun masih ada yayasan yang tidak menyesuaikan anggaran dasarnya. Hal ini terlihat pada masa berlaku dari Undang-Undang Yayasan yaitu mulai berlaku 1 (satu) tahun terhitung sejak tanggal diundangkan pada tanggal 6 Oktober 2004. Sehingga ketentuan dalam pasal 71 Undang-Undang Yayasan yang memberikan jangka waktu paling lambat 3 (tiga) tahun seharusnya sudah berakhir pada tanggal 6 Oktober 2008 lalu.

Dengan tidak melekatnya status badan hukum yang dimiliki oleh yayasan tersebut maka atas segala perbuatan hukum yang dilakukan oleh pengurus yayasan atas nama yayasan tersebut terhadap pihak ketiga bukan lagi menjadi tanggung jawab yayasan, melainkan menjadi tanggung pengurus yayasan secara tanggung renteng atas segala perbuatan hukum yang dilakukannya atas nama yayasan tersebut. ${ }^{12}$ Sehingga apabila terjadi kerugian yang dirasakan oleh pihak ketiga atas tindakan yang dilakukan oleh organ yayasan bukan lagi menjadi tanggung jawab yayasan, melainkan menjadi tanggung renteng antar organ yayasan tersebut.

\section{Perbuatan Hukum yang Dapat Dilakukan oleh Yayasan}

Yayasan dapat melakukan perbuatan hukum tidaklah lepas dari pandangan bahwa yayasan adalah suatu badan hukum. Istilah Badan hukum (Rechtpersoon) berarti bahwa orang (Persoon) yang diciptakan oleh hukum. ${ }^{13}$ Badan hukum sebagai subyek hukum dapat bertindak dalam lalu lintas hukum untuk melakukan suatu perbuatan hukum seperti manusia. Namun untuk mengetahui hakikat dari badan hukum tersebut, dapat dilihat dari beberapa teori badan hukum yaitu:

\section{Teori Fiksi}

Teori dari Friedrich Carl von Savigny ini mengemukakan bahwa badan hukum adalah sebuah fiksi yang dibuat oleh pemerintah atau negara. Badan hukum

\footnotetext{
${ }^{12}$ Pasal 13 A Undang-Undang Nomor 28 tahun 2004 tentang Perubahan Atas Undang-Undang Nomor 16 tahun 2001 tentang Yayasan.

${ }^{13}$ Komariah, Hukum Perdata (UMM Press 2013).[17].
} 
sesungguhnya tidak ada akan tetapi orang menghidupkannya dalam bayangan sehingga badan hukum dapat diakui sebagai subyek hukum layaknya manusia. ${ }^{14}$

\section{Teori Organ}

Teori organ muncul sebagai bentuk reaksi dari adanya teori fiksi. Teori ini dipelopori oleh Otto von Gierke, yang menurutnya badan hukum itu ialah seperti manusia yang memiliki kehendak dengan menggunakan perantara alat-alat atau organ-organ badan untuk dapat mencapai kehendaknya. Karena organ hanya sebagai perantara dari badan hukum, maka segala keputusan yang diambil adalah kehendak dari badan hukum tersebut, bukan kehendak dari organ-organnya. ${ }^{15}$

\section{Teori Harta Kekayaan Bertujuan}

Teori ini dipelopori oleh A. Brinz yang menyatakan bahwa hanya manusialah yang dapat menjadi subyek hukum. Sehingga badan hukum menurut teori ini tidak termasuk sebagai subyek hukum dan hak-hak yang diberikan kepada badan hukum sebenarnya adalah hak-hak yang tidak ada pemiliknya. Karena itu sebagai penggantinya adalah suatu harta kekayaan yang terikat oleh suatu tujuan. ${ }^{16}$

\section{Teori Kekayaan Bersama}

Teori ini dipelopori oleh Planiol yang menyatakan bahwa hak dan kewajiban badan hukum itu pada hakikatnya adalah hak dan kewajiban anggota bersamasama. Sehingga antara anggota dan badan hukum bersama-sama pula dalam hal bertanggung jawab. Harta kekayaan badan hukum adalah hak milik dari anggotaanggota. ${ }^{17}$

Dengan melekatnya status badan hukum pada suatu yayasan, barulah yayasan tersebut dalam lalu lintas hukum dapat melakukan perbuatan hukum layaknya manusia. Badan hukum mempunyai kemampuan dalam hukum perikatan dan hukum kebendaan. Badan hukum yang dalam hal ini adalah yayasan dapat melakukan hubungan-hubungan hukum atau mengadakan perjanjian-perjanjian

\footnotetext{
${ }^{14}$ Chidir ali, Badan Hukum (Alumni 2014).[31].

${ }^{15}$ ibid.[32].

${ }^{16}$ Ali rido, Badan Hukum Dan Kedudukan Badan Hukum Perseroan, Perkumpulan, Koperasi, Yayasan, Wakaf (Alumni 2012).[8].

${ }^{17}$ ibid. [9].
} 
baik secara tertulis maupun tidak tertulis dengan pihak ketiga. Badan hukum yayasan pula memiliki hak-hak perdata terhadap kebendaan baik atas benda-benda bergerak, benda-benda tidak bergerak, benda-benda berwujud, maupun bendabenda tidak berwujud. Serta badan hukum yayasan dapat memakai nama dan dapat pula melakukan perbuatan-perbuatan melanggar hukum. ${ }^{18}$

Dalam segala tindakan, badan hukum dipandang seolah-olah seperti manusia yang dimungkinkan untuk melakukan suatu perbuatan melanggar hukum. Pengurus dapat dikatakan bertindak sebagai organ untuk mewakili badan hukum Yayasan ketika ia dalam melakukan tindakan kepengurusan Yayasan sesuai dengan maksud dan tujuan Yayasan serta didasarkan atas wewenang yang diberikan oleh UndangUndang dan Anggaran Dasar beserta dengan batasan-batasannya. Dengan dmikian perbuatan badan hukum Yayasan tersebut menjadi terikat dan perbuatan terhadap perbuatan hukum tersebut dapat dipertanggungjawabkan. Namun sebaliknya jika organ Yayasan melakukan tindakan hukum diluar wewenangnya, maka badan hukum hanya terikat dan dapat dipertanggungjawabkan jika tindakan tersebut menguntungkan badan hukum, atau suatu organ yang lebih tinggi kedudukannya dan berkompeten untuk itu kemudian menyetujui tindakan tersebut. Dengan pengesahan ini maka perbuatan-perbuatan diluar wewenangnya yang tadinya dianggap batal menjadi berlaku.

\section{Pertanggungjawaban Pengurus Terhadap Tindakan yang Dilakukan Atas Nama Yayasan}

Pertanggungjawaban hukum pada subyek hukum yang berbentuk badan hukum berbeda dengan subyek hukum yang berupa manusia. Manusia sebagai subyek hukum apabila melakukan suatu perbuatan hukum dapat langsung dapat ditunjuk siapa yang dapat dikenai pertanggungjawaban hukum atas perbuatan yang dilakukan. Dalam badan hukum sebagai subyek hukum, haruslah ditentukan terlebih dahulu siapa yang mempunyai kewenangan untuk melakukan perbuatan

\footnotetext{
${ }^{18}$ Chidir ali.Op.Cit.[168].
} 
hukum tersebut. Hal ini karena dalam suatu badan hukum terdapat organ-organ yang memiliki tugas dan fungsi yang berbeda-beda satu sama lain.

Yayasan dalam melakukan kegiatannya mungkin saja melakukan perbuatan melanggar hukum. Perbuatan melanggar hukum yang dilakukan oleh suatu badan hukum yang terdiri dari organ-organ kepengurusan, maka perlu ditentukan siapa pihak yang dapat dimintai pertanggungjawaban atas perbuatan melanggar hukum yang dilakukan yayasan tersebut. Yayasan sebagai badan hukum, terdapat organorgan yayasan yang mempunyai tugas dan wewenang yang berbeda antara satu sama lain, organ-organ tersebut meliputi Pembina, Pengurus dan Pengawas. Didalam Undang-Undang Yayasan, pertanggungjawaban organ dibagi menjadi tiga bagian yaitu: 1) Tanggung jawab yang dilakukan antara organ dan Yayasan; 2) Tanggung jawab yang dilakukan secara perseorangan; dan 3) Tanggung jawab yang dilakukan secara renteng antar-organ.

Pengurus sebagai salah satu organ dari yayasan memiliki peran ganda dalam pengelolaan yayasan. Ada dua sisi yang harus diperhatikan dalam wewenang Pengurus, yaitu kekuasaan Pengurus untuk mewakili, guna bertindak untuk serta atas nama yayasan. Sedangkan pada sisi lain, kewenangan Pengurus mewakili yayasan ataupun kewenangan bertindak pengurus dengan segala persyaratan serta pembatasannya sebagaimana ditentukan dalam anggaran dasar. ${ }^{19}$

Pengurus dapat bertindak sebagai Pengurus dari badan hukum Yayasan, dan dapat pula ia bertindak secara pribadi atas dirinya sendiri. Apabila Pengurus melakukan suatu perbuatan hukum untuk dan atas nama Yayasan dalam kapasitasnya sebagai Pengurus, maka Yayasan tersebut dapat digugat untuk perbuatan-perbuatan melanggar hukum yang dilakukan oleh Pengurus tersebut. Pengurus selain bertindak sebagai wakil dari Yayasan, ia bisa pula bertindak sebagai pribadi dirinya sendiri dan dapat dipertanggungjawabkan. Dalam melakukan tindakan kepengurusan, tidak ditutup kemungkinan bahwa Pengurus dapat melakukan kesalahan-kesalahan pribadi yang dapat menimbulkan kerugian bagi Yayasan itu sendiri maupun terhadap

\footnotetext{
${ }^{19}$ Chatamarrasjid Ais, Badan Hukum Yayasan (PT Citra Aditya Bakti 2006).[111].
} 
pihak ketiga. Sehingga Pengurus diwajibkan untuk bertanggungjawab dalam bentuk mengganti kerugian secara pribadi. Kesalahan-kesalahan pribadi yang dilakukan oleh Pengurus terjadi bisa saja karena kelalaiannya dan kurang berhati-hati dalam bertindak hingga menyebabkan timbulnya kerugian.

Melihat besarnya wewenang yang dimiliki Pengurus dalam mengelola Yayasan, maka terlihat bahwa Pengurus lah yang kemudian harus memikul tanggung jawab atas segala tindakan-tindakan yang dilakukannya atas nama Yayasan baik kepada Yayasan itu sendiri maupun terhadap pihak ketiga. Hal ini karena UndangUndang Yayasan serta Anggaran Dasar telah memberikan kewenangan kepada Pengurus untuk melaksanakan kepengurusan Yayasan dan kewenangan untuk mewakili Yayasan baik didalam maupun diluar pengadilan.

Suatu kasus di Surabaya, dimana sebuah yayasan yaitu Yayasan IMKA yang telah berdiri sejak tahun 1946 yang berkedudukan di Jalan Kombes Pol. M. Duryat Nomor 9 Surabaya-Jawa Timur namun baru melakukan pengesahan yayasan ke Kementrian Hukum dan Hak Asasi Manusia Republik Indonesia pada tanggal 26 Juni 2013. ${ }^{20}$

Berdasarkan pasal 71 Undang-Undang Yayasan tersebut, dapat diartikan bahwa Yayasan IMKA yang tidak melakukan penyesuaian anggaran dasarnya dalam tenggat waktu yang diberikan oleh Undang-Undang Yayasan yaitu dari tahun 2005 hingga tahun 2008 seharusnya tidak dapat menggunakan kata Yayasan didepan namanya. Yang artinya bahwa yayasan tersebut bukanlah suatu badan hukum lagi. Karena Undang-Undang Yayasan telah menentukan jangka waktu bagi yayasan untuk menyesuaikan anggaran dasarnya dengan ketentuan yang ada di dalam Undang-Undang Yayasan yaitu paling lambat 3 (tiga) tahun sejak tanggal diundangkannya, seharusnya jangka waktu bagi yayasan untuk dapat melaksanakan penyesuaian anggaran dasar sesuai dalam pasal 71 Undang-Undang Yayasan tersebut sudah berakhir pada tanggal 6 Oktober 2008 lalu.

Dengan tidak diakuinya sebagai badan hukum, sudah tentu bahwa yayasan tersebut tidak dapat melakukan perbuatan hukum sebagaimana yayasan yang telah

\footnotetext{
${ }^{20}$ Wawancara dengan Kepala Sekolah TK Yayasan IMKA Joan Maria Louise Mantiri, Kantor Yayasan IMKA Surabaya, Tanggal 13 November 2015.
} 
diakui sebagai badan hukum. Teori-teori mengenai badan hukum tidak berlaku dalam kasus ini, sehingga apabila yayasan tersebut melakukan perbuatan hukum maka atas perbuatan tersebut tidak dapat dimintai pertanggungjawaban kepada yayasan, melainkan yang dapat dimintai pertanggungjawaban adalah Pengurus yang secara pribadi menanggung perbuatan tersebut sampai dengan harta kekayaan pribadi apabila terjadi kerugian baik terhadap yayasan itu sendiri maupun terhadap pihak ketiga.

Namun jika dilihat pada fakta yang ada di masyarakat, Yayasan IMKA tersebut tetap melakukan kegiatan yayasan seolah-olah yayasan tersebut telah melakukan penyesuaian anggaran dasar. Pengurus sebagai organ yayasan yang bertanggungjawab penuh dalam hal melaksanakan kepengurusan yayasan dan Pengurus juga berwenang untuk mewakili yayasan baik didalam maupun diluar pengadilan menjadi tidak efektif apabila dikaitkan dengan kasus diatas. Karena Undang-Undang Yayasan telah memberikan suatu aturan apabila pengurus yayasan yang melakukan suatu perbuatan hukum atas nama yayasan sebelum yayasan tersebut memperoleh status badan hukum maka atas perbuatannya tersebut pengurus bertanggung jawab secara tanggung renteng.

Dengan demikian Pengurus dapat dikatakan melakukan tindakan ultra vires yaitu keadaan dimana Pengurus dalam menjalankan perbuatan mewakili badan hukum, Pengurus telah melakukan perbuatan secara bertentangan atau tidak sesuai dengan Anggaran Dasar badan yang bersangkutan. ${ }^{21}$ Dalam hal ini Pengurus tidak berwenangan untuk melakukan perbuatan mewakili badan hukum karena hal tersebut diluar batas kecakapannya. Pengurus mendapatkan wewenang untuk melaksanakan kepengurusan Yayasan dan berwenang untuk mewakili Yayasan baik didalam maupun diluar pengadilan berdasarkan pada Undang-Undang dan Anggaran Dasar suatu Yayasan. Namun jika suatu Yayasan yang belum menyesuaikan ketentuan Anggaran Dasarnya, maka Anggaran Dasar tersebut menjadi tidak berkekuatan hukum yang tetap dan terhadap perbuatan yang dilakukan oleh Pengurus tersebut haruslah batal demi hukum. Hal ini disebabkan karena belum disahkannya akta

${ }^{21}$ Rudhi Prasetya, Yayasan Dalam Teori Dan Praktik (Sinar Grafika 2012).[17]. 
pendirian Yayasan, dan berarti pula bahwa tentang tata cara pengangkatan Pengurus yang diatur dalam Anggaran Dasarnya belum sah. ${ }^{22}$

Menurut Rudhi Prasetya, yayasan yang belum mendapatkan pengesahan atau belum mengajukan pengesahan kepada Menteri bukan berarti bahwa yayasan tersebut tidak dapat melakukan perbuatan hukum. ${ }^{23}$ Yayasan tersebut tetap dapat melakukan perbuatan hukum yang dalam hal ini adalah kewenangan Pengurus untuk melaksanakan kepengurusan yayasan untuk bertindak untuk dan atas nama yayasan. Namun yayasan belum bisa dimintai pertanggungjawaban karena yayasan belum memiliki status badan hukum yang disahkan oleh Menteri. Sehingga terhadap perbuatan hukum yang telah dilakukan Pengurus atas nama yayasan dalam hal akta pendirian yayasan tersebut belum disahkan menjadi badan hukum dan yayasan tersebut belum memperoleh status badan hukum dari Menteri, maka perbuatan tersebut tidak mengikat bagi badan hukum yayasan, dan para Pengurus pribadilah yang terikat terhadap perbuatan hukum tersebut sehingga atas segala kerugian yang ditimbulkan baik terhadap yayasan maupun terhadap pihak ketiga menjadi tanggung jawab Pengurus secara tanggung renteng sampai kepada harta kekayaan pribadi.

Disinilah kemudian muncul fungsi bahwa Yayasan harus didaftarkan kemudian mendapatkan pengesahan dari Menteri sebagai badan hukum dan diumumkan dalam Tambahan Berita Negara Indonesia. Dengan telah melakukan pendaftaran dan pengumuman, semua perbuatan Pengurus dalam batas-batas wewenangnya merupakan perbuatan-perbuatan badan hukum itu sendiri dengan pertanggungjawaban badan hukum itu sendiri pula. Sehingga jelas bahwa dengan adanya pendaftaran dan pengumuman Yayasan sebagai badan hukum menghilangkan adanya pertanggungjawaban para Pengurus secara pribadi dan mengalihkannya kepada badan hukum itu. ${ }^{24}$

\footnotetext{
${ }^{22}$ Suyud Margiono.Op.Cit.[82].

${ }^{23}$ Rudhi Prasetya.Op.Cit.[43].

${ }^{24}$ Ali rido.Op.Cit.[33].
} 


\section{Kesimpulan}

Berdasarkan permasalahan yang telah diuraikan, maka dapat disimpulkan bahwa status hukum suatu yayasan yang hingga jangka waktu penyesuaian Anggaran Dasar sebagaimana diberikan pasal 71 Undang-Undang Yayasan, terhadap yayasan yang tidak melakukan penyesuaian anggaran dasar maka berdasarkan hukum yang berlaku, yayasan tersebut tidak lagi dapat menggunakan kata "Yayasan" didepan namanya dan dapat dibubarkan berdasarkan putusan pengadilan atas permohonan kejaksaan atau pihak yang berkepentingan. Namun dengan berlakunya Peraturan Pemerintah Nomor 2 tahun 2013 tentang Perubahan Atas Peraturan Pemerintah Nomor 63 tahun 2008 tentang Pelaksanaan Undang-Undang tentang Yayasan maka yayasan yang sudah kehilangan status badan hukumnya dapat diakui kembali sebagai badan hukum dengan melakukan permohonan pengesahan akta pendirian yayasan.

Tidak adanya status badan hukum yang melekat pada suatu yayasan, berakibat bahwa terhadap perbuatan yang dilakukan oleh yayasan yang belum menyesuaikan dengan Undang-Undang Yayasan menjadi tidak mengikat bagi badan hukum yayasan tersebut. Melainkan menjadi tanggung jawab penuh pengurus yang secara tanggung renteng sampai dengan harta kekayaan pribadi atas segala tindakan dan kerugian yang dilakukan oleh pengurus itu sendiri maupun terhadap pihak ketiga.

\section{Daftar Bacaan}

\section{Buku}

Alex Lanur OFM, Logika Selayang Pandang (Kanisius 1983).

Ali rido, Badan Hukum Dan Kedudukan Badan Hukum Perseroan, Perkumpulan, Koperasi, Yayasan, Wakaf (Alumni 2012).

Anwar Borahima, Kedudukan Yayasan Di Indonesia Eksistensi, Tujuan, Dan Tanggung Jawab Yayasan (Kencana 2010).

Chatamarrasjid Ais, Badan Hukum Yayasan (PT Citra Aditya Bakti 2006).

Chidir ali, Badan Hukum (Alumni 2014).

Komariah, Hukum Perdata (UMM Press 2013). 
Peter Mahmud Marzuki, Penelitian Hukum (Kencana Prenadamedia Group 2014).

Rochmat Soemitro, Hukum Perseroan Terbatas, Yayasan Dan Wakaf(Eresco 1993).

Rudhi Prasetya, Yayasan Dalam Teori Dan Praktik (Sinar Grafika 2012).

Suyud Margiono, Badan Hukum Yayasan Dinamika Praktek, Efektifitas \& Regulasi Di Indonesia (Pustaka Reka Cipta 2015).

\section{Makalah}

Ana Ferliana, Pelatihan Penggunaan Layanan AHU Online 'Badan Hukum Yayasan dan Perkumpulan Pasca Disahkannya UU ORMAS', disampaikan di Ruang Pertemuan Hotel Harris Surabaya Hotel (2015).

\section{Peraturan Perundang-undangan}

Undang-Undang Republik Indonesia Nomor 28 tahun 2004 tentang Perubahan Atas Undang-Undang Nomor 16 tahun 2001 tentang Yayasan (Lembaran Negara Republik Indonesia tahun 2004 nomor 115).

Undang-Undang Nomor 16 tahun 2001 tentang Yayasan (Lembaran Negara Republik Indonesia tahun 2001 nomor 112).

Peraturan Pemerintah Republik Indonesia Nomor 2 tahun 2013 tentang Perubahan Atas Peraturan Pemerintah Republik Indonesia Nomor 63 tahun 2008 tentang Pelaksanaan Undang-Undang tentang Yayasan (Lembaran Negara Republik Indonesia tahun 2013 nomor 2).

Peraturan Pemerintah Republik Indonesia Nomor 63 tahun 2008 tentang Pelaksanaan Undang-Undang tentang Yayasan (Lembaran Negara Republik Indonesia tahun 2008 nomor 134).

Peraturan Menteri Hukum dan Hak Asasi Manusia Republik Indonesia Nomor 5 tahun 2014 tentang Pengesahan Badan Hukum Yayasan (Lembaran Negara Republik Indonesia tahun 2014 nomor 393).

Peraturan Menteri Hukum dan Hak Asasi Manusia Republik Indonesia Nomor M.HH-02.AH.01.01 tahun 2011 tentang Daftar Yayasan (Lembaran Negara Republik Indonesia tahun 2011 nomor 622).

Peraturan Menteri Hukum dan Hak Asasi Manusia Republik Indonesia Nomor M.HH-02.AH.02.01 tahun 2010 tentang Tata Cara Pengumuman Yayasan Dalam Tambahan Berita Negara Republik Indonesia (Lembaran Negara Republik Indonesia tahun 2010 nomor 335). 
--Halaman ini sengaja dibiarkan kosong-- 